\title{
Physical Laboratory Testing
}

National Cancer Institute

\section{Source}

National Cancer Institute. Physical Laboratory Testing. NCI Thesaurus. Code C113079.

Testing of specimens or materials for various physical properties. 